\title{
DELINEASI DAERAH PROSPEK PANAS BUMI BERDASARKAN ANALISIS KELURUSAN CITRA LANDSAT DI CANDI UMBUL - TELOMOYO, PROVINSI JAWA TENGAH
}

Oleh:

\author{
Dudi Hermawan, Yuanno Rezky \\ Pusat Sumber Daya Geologi \\ Jln. Soekarno - Hatta No. 444 Bandung
}

SARI

Sistem rekahan yang merupakan media bagi fluida panas bumi untuk muncul ke permukaan dapat didelineasi dengan kelurusan pada citra landsat. Kelurusan-kelurusan yang diperoleh dari hasil analisis citra landsat sangat membantu dalam analisis struktur geologi, tetapi hal tersebut belum cukup dalam suatu kegiatan eksplorasi panas bumi. Perlu juga diketahui bagian mana yang memiliki struktur geologi paling intensif dan pola umum dari struktur geologi yang berkaitan dengan pembentukan sistem panas bumi daerah tersebut. Peta kerapatan kelurusan (lineament density map) akan sangat membantu dalam analisis struktur geologi kepanas-bumian sehingga bisa digunakan untuk mendelineasi perkiraan daerah prospek panas bumi.

Analisis kelurusan struktur di daerah panas bumi Candi Umbul-Telomoyo menunjukkan bahwa anomali kerapatan struktur geologi yang tinggi dan diperkirakan sebagai daerah prospek panas bumi adalah di bagian utara kerucut muda Gunung Telomoyo. Anomali ini tersebar dari lereng baratlaut kerucut muda Gunung Telomoyo ke utara-timurlaut sampai daerah Keningar dan Candi Dukuh dengan luas $39 \mathrm{~km}^{2}$ serta di sekitar manifestasi Candi Umbul dengan luas 7 $\mathrm{km}^{2}$. Hal ini didukung oleh kondisi geologi permukaan berupa pemunculan manifestasi mata air panas dan sebaran batuan ubahan bertipe argilik hingga argilik lanjut yang diasumsikan sebagai hasil interaksi fluida hidrotermal dengan batuan sekitar melalui jalur-jalur rekahan.

Kata Kunci : kelurusan, citra landsat, struktur geologi, daerah prospek.

\section{ABSTRACT}

A fractures system that act as conduit for hydrothermal fluid to flow upward to the surface might be delineated by lineament derived from landsat imagery. The lineaments analysis of landsat imagery is very helpful to analyze the geological structure. However this method is not quite useful for a geothermal exploration. Moreover it should also to be considered which part of the area has the most intensive geological structure and recognized the main pattern of the geological structure which is related to geothermal system. Lineament density map will greatly usefull in the analysis of geothermal geological structure so it can be applied to delineate area of geothermal prospect estimation.

Lineament analysis on Candi Umbul-Telomoyo geothermal area shows that area contain high density anomaly of the geological structure related to geothermal prospect is located at northern part of the young cone of Mount Telomoyo. This anomaly spreads from northwestern flank of young Mount Telomoyo cone and extends to the north-northeast to Keningar and Candi Dukuh area and around geothermal manifestation of Candi Umbul with areas of $39 \mathrm{~km}^{2}$ and $7 \mathrm{~km}^{2}$ respectively. This anomaly is supported by geological conditions with the occurrence of hotspring and an area of altered rock (argillic to advanced argillic type of alteration) which is assumed as the result of interaction of hydrothermal fluid with the surrounding rock through fracture.

Keywords : lineament, landsat imagery, structural geology, geothermal prospect area 


\section{PENDAHULUAN}

Analisis kelurusan citra landsat adalah salah satu metode yang digunakan untuk menentukan daerah yang memiliki anomali tinggi kerapatan struktur geologi yang dibentuk oleh hubungan dari patahan dan rekahan. Rekahan terbentuk oleh aktivitas tektonik, dan perkembangannya tergantung pada deformasi batuan selama aktifitas tektonik, seperti lipatan dan patahan.

Struktur ini berpotensi sebagai zona permeabel yang dapat berperan sebagai media bagi fluida panas mengalir dari reservoir di kedalaman dangkal. Telah terbukti dalam eksplorasi panas bumi dan eksploitasi bahwa zona permeabel adalah target pemboran yang signifikan untuk menemukan sumur produktif (Soengkono, 1999a dan 1999b).

Sampai saat ini metode analisis kelurusan pada citra landsat untuk eksplorasi panas bumi masih jarang dilakukan. Oleh karena itu, makalah ini dibuat untuk menunjukkan bahwa analisis struktur geologi berdasarkan penarikan kelurusan citra landsat sangatlah diperlukan sebagai data awal dalam eksplorasi panas bumi.

Analisis kelurusan citra landsat ini dilakukan di daerah panas bumi Candi Umbul-Telomoyo, Provinsi Jawa Tengah yang secara administratif dibatasi di bagian utara oleh Kabupaten Semarang, di bagian selatan oleh Kabupaten Magelang, di bagian barat oleh Kabupaten Temanggung, di bagian tenggara oleh Kabupaten Boyolali, dan di bagian timur oleh Kota Salatiga (Gambar 1).

Hasil analisis ini dapat digunakan untuk menunjang dan melengkapi data hasil survei terpadu geologi dan geokimia serta survei magnetotellurik yang dilakukan oleh Pusat Sumber Daya Geologi, Badan Geologi pada tahun 2010.

\section{TATANAN GEOLOGI}

Perkembangan tektonik di Indonesia tidak dapat dipisahkan dari pertemuan atau interaksi antara lempeng Eurasia dan Samudera Hindia. Interaksi ini menghasilkan suatu tatanan geologi yang khas di Pulau Jawa. Secara geologi, Pulau Jawa merupakan suatu komplek sejarah

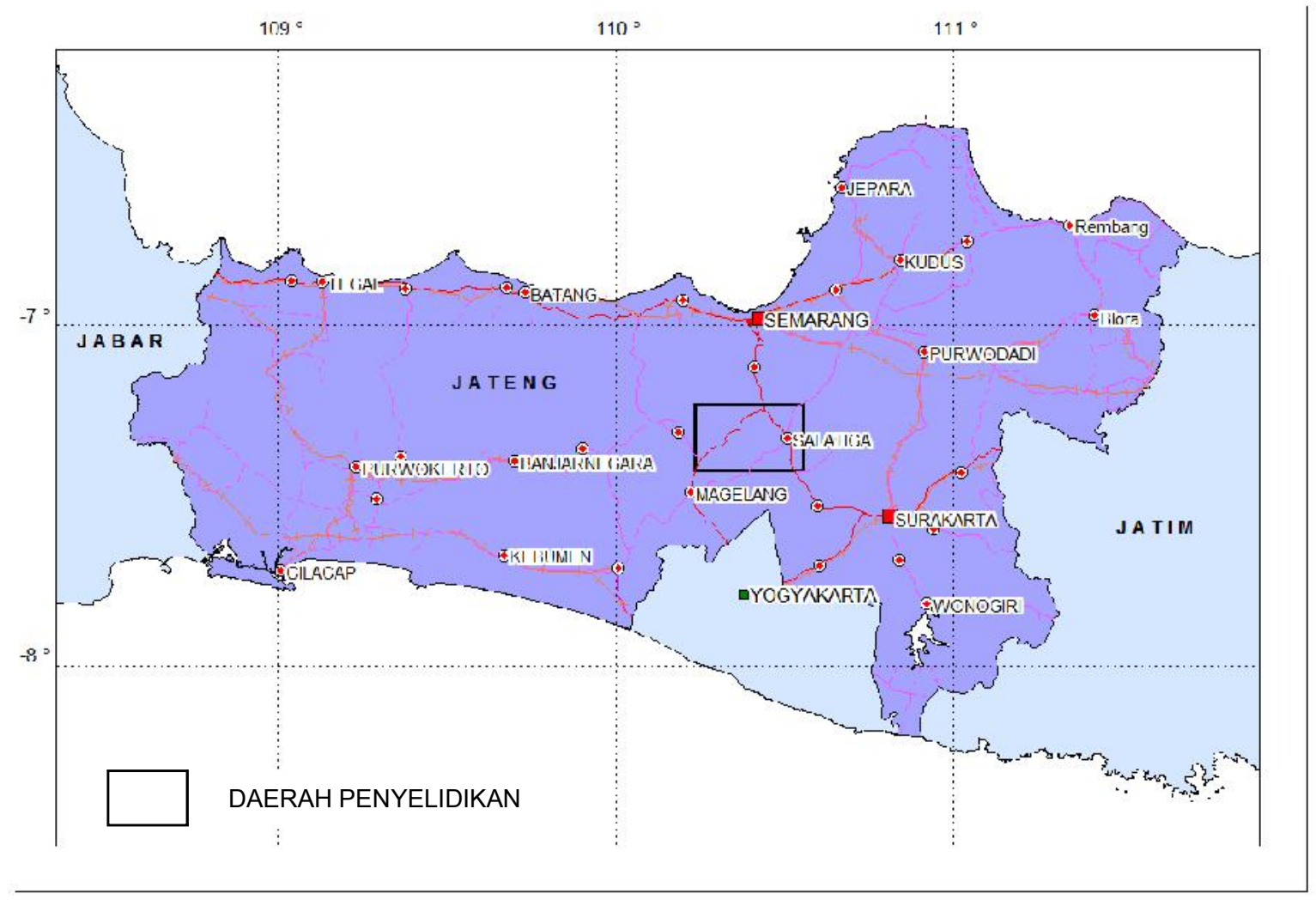

Gambar 1. Peta Lokasi Daerah Penyelidikan 
penurunan basin, pensesaran, perlipatan dan vulkanisme di bawah pengaruh stress regime yang berbeda-beda dari PaleogenNeogen. Secara umum, ada tiga arah pola umum struktur geologi yaitu arah timurlaut-baratdaya yang disebut pola Meratus, arah utara-selatan atau pola Sunda dan arah timur-barat yang disebut pola Jawa (Gambar 2).

Secara fisiografis daerah panas bumi Candi Umbul-Telomoyo termasuk pada zona North Serayu Range bagian ujung timur. Pada zona ini terbentuk suatu kompleks gunungapi yang memanjang berarah baratlaut-tenggara yaitu rangkaian Gunung Ungaran-Gunung Telomoyo-Gunung Merbabu-Gunung Merapi yang berada pada lingkungan geologi vulkanik Kuarter. Produk dari gunungapi tersebut berupa batuan piroklastik dan lava dengan komposisi andesit-basaltik.

Batuan tertua yang tersingkap di daerah Candi Umbul-Telomoyo adalah batuan sedimen berumur Miosen Tengah yang merupakan batuan sedimen turbidit dan diendapkan di lingkungan neritik. Pada Kala Pliosen Atas terjadi proses pengangkatan yang diikuti oleh pemunculan aktivitas vulkanik Ungaran Tua pada Kala Plistosen Awal yang diindikasikan dengan terbentuknya satuan lava Ungaran-1. Aktivitas vulkanik juga terjadi di sebelah tenggara Ungaran yaitu aktivitas vulkanik Telomoyo-1 yang menghasilkan produk lava dan batuan piroklastik. Letusan Gunung Telomoyo-1 menyebabkan terjadinya kekosongan di perut bumi sehingga akibat gaya gravitasi terjadi collapse di bagian tengah daerah survei yang dicirikan dengan adanya struktur rim kaldera depresi. Di bagian depresi yang merupakan zona lemah ini kemudian muncul kembali aktivitas vulkanik Telomoyo-2 yang menghasilkan produk lava dan batuan piroklastik. Aktivitas vulkanik ini terus berlanjut hingga membentuk kerucut Telomoyo sekarang dan kerucut Andong. Pada akhir aktivitas vulkanik Telomoyo terjadi erupsi setempat pada zona sesar yang membentuk satuan kerucut piroklastik berupa scoria cone. Hampir bersamaan dengan aktivitas vulkanik terakhir komplek Telomoyo, di sebelah utara (Ungaran) dan sebelah selatan (Merbabu) juga terjadi aktivitas vukanik yang menghasilkan produk lava dan batuan piroklastik.

Selanjutnya, proses erosi yang berlangsung sampai saat ini menghasilkan endapan lahar dan aluvium seperti yang banyak terdapat di sepanjang pedataran dan sungai-sungai besar (Gambar 3).

Struktur geologi yang berkembang terdiri dari struktur rim kaldera dan sesarsesar normal berarah baratdaya-timurlaut yang terbentuk akibat aktivitas Gunung Telomoyo, serta sesar-sesar mendatar berarah relatif utara-selatan dan baratlauttenggara yang merupakan struktur regional dan sebagian sudah ditutupi oleh produk batuan yang lebih muda (Tim Survei Terpadu Panas Bumi, PSDG, 2010).

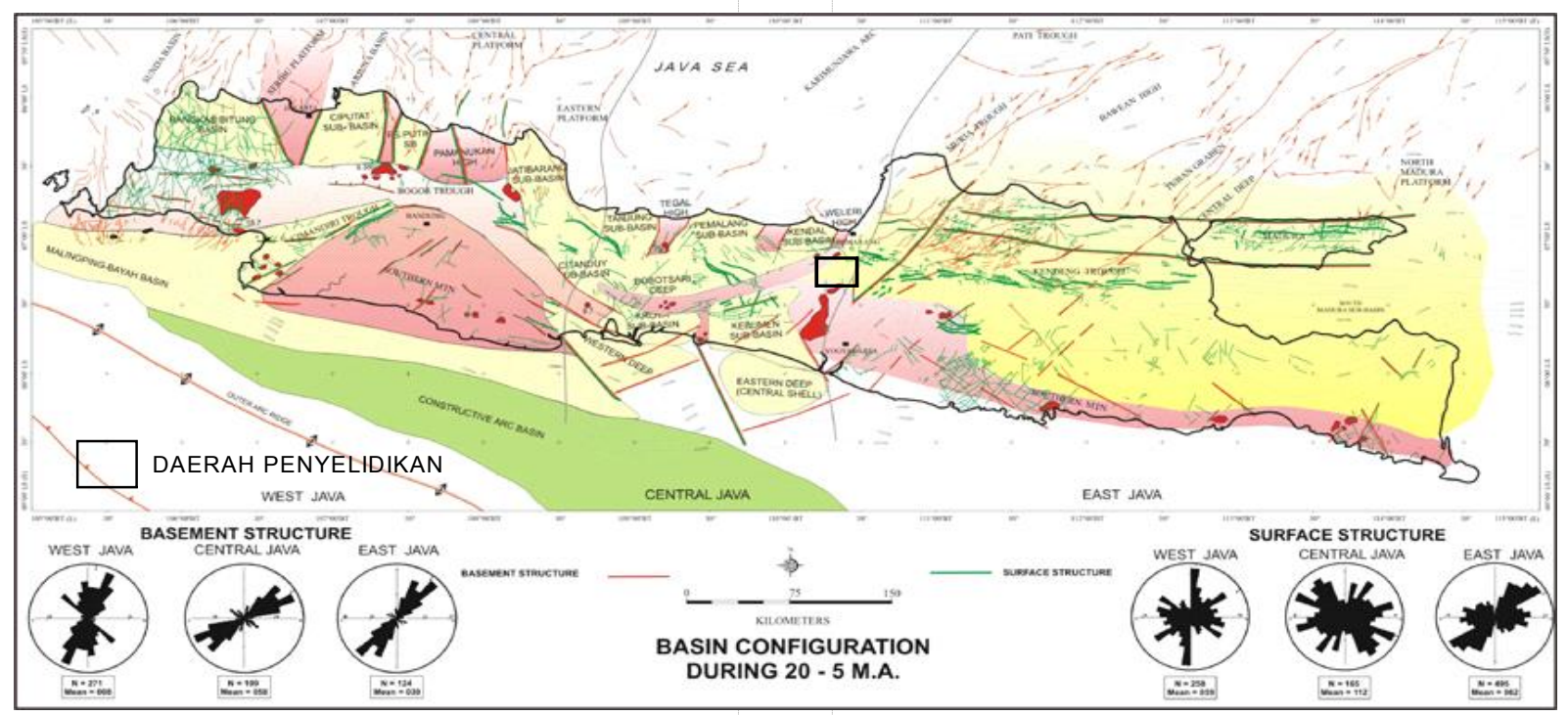

Gambar 2. Peta Pola Struktur Pulau Jawa (Sribudiyani, dkk, 2003) 


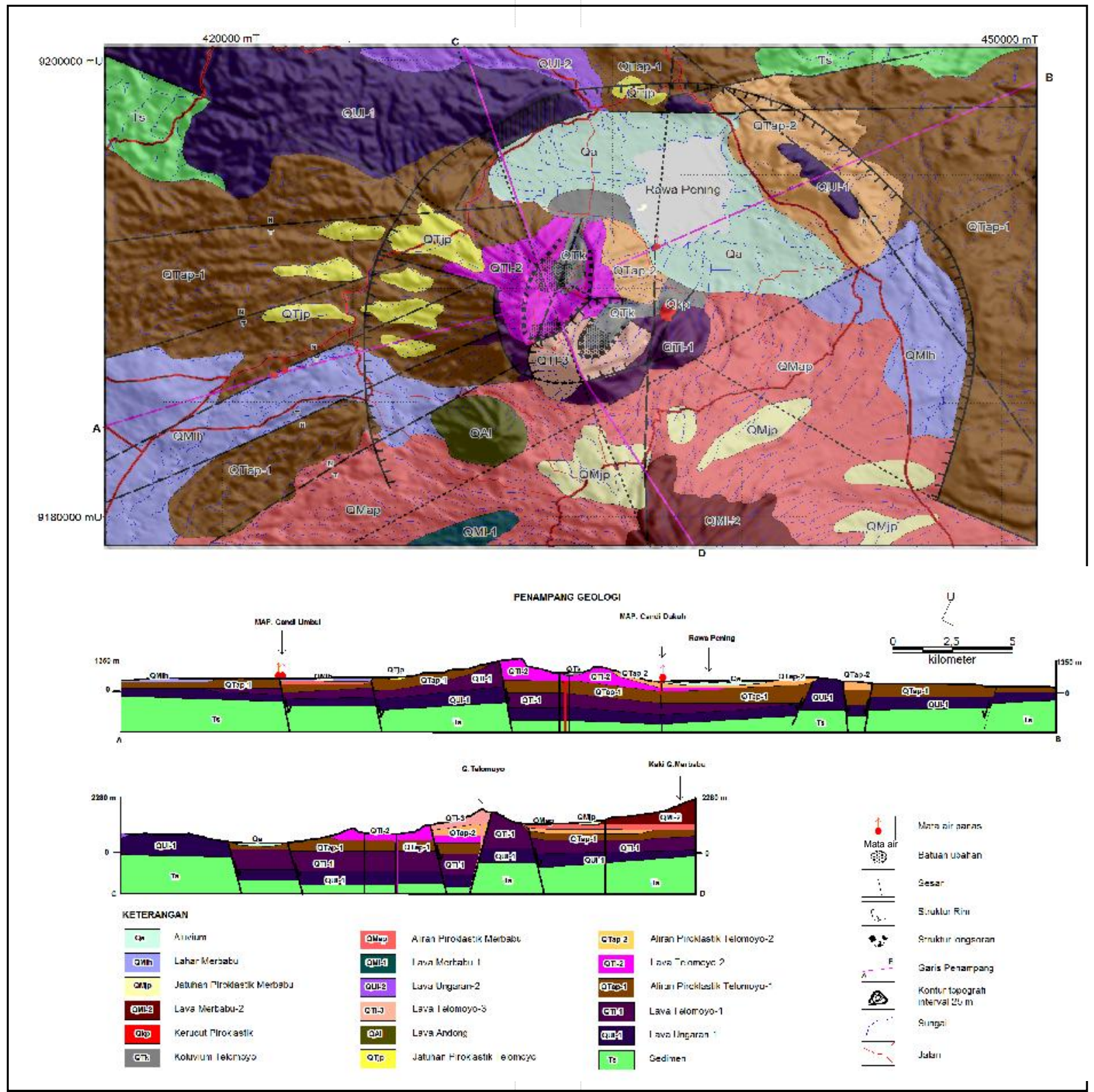

Gambar 3. Peta Geologi Daerah Panas Bumi Candi Umbul-Telomoyo (Tim Survei Terpadu Panas Bumi, PSDG, 2010)

\section{MANIFESTASI PANAS BUMI}

Manifestasi panas bumi di daerah Candi Umbul-Telomoyo terdiri dari mata air panas yang tersebar di tiga lokasi yaitu mata air panas Candi Dukuh dengan temperatur berkisar antara $35-36^{\circ} \mathrm{C}$, serta mata air panas Candi Umbul dan Pakis Dadu dengan temperatur berkisar antara $35-36{ }^{\circ} \mathrm{C}$.

Selain manifestasi berupa mata air panas, di daerah ini ditemukan juga batuan ubahan bertipe argilik hingga argilik lanjut yang tersebar cukup luas di tiga lokasi yaitu di daerah Sepakung, Keningar dan Kendal Duwur.

\section{METODOLOGI}

Aplikasi dari metode kerapatan kelurusan ini sangat penting diterapkan pada daerah yang memiliki potensi panas bumi. $\mathrm{Hal}$ ini disebabkan manifestasi panas bumi muncul dikarenakan adanya interaksi fluida panas dengan batuan sekitar pada zona patahan dan rekahan yang intensif. Dari citra landsat dapat diamati kelurusan-kelurusan yang diperkirakan merupakan struktur geologi berupa perbedaan kontras rona pada citra satelit. Kelurusan-kelurusan inilah yang mengontrol tinggi-rendahnya anomali kerapatan kelurusan. 
Untuk mencapai sasaran diatas, metode yang dilakukan terdiri dari penajaman citra, filtering, dan penarikan kelurusan. Kelurusan ditarik secara manual berdasarkan kesamaan color value. Kelurusan yang didapat merupakan hasil interpretasi karena kelurusan yang tidak mencerminkan struktur tidak diperhitungkan sebagai kelurusan, misalnya noise-noise dari atmosfer, awan, jalan raya, dan lain sebagainya. Arah dari kelurusan ini kemudian diklasifikasikan ke dalam beberapa arah utama. Dari pengklasifikasian ini dapat dilihat pola utama struktur yang berkembang, sehingga bisa diperkirakan pola struktur yang mengontrol pemunculan manifestasi panas bumi. Setelah itu dilakukan pembuatan gridding untuk mendapatkan peta kerapatan patahan dan rekahan (fault and fracture density map) serta peta kerapatan perpotongan patahan dan rekahan (fault and fracture dilational map).

Grid area yang paling sesuai untuk analisis kerapatan kelurusan suatu lapangan panas bumi adalah $1 \mathrm{~km}^{2}$ dan unit yang diperoleh adalah $\mathrm{km} / \mathrm{km}^{2}$ Soengkono (1999).

Dari ke dua peta tersebut setelah dikompilasikan dapat ditarik deliniasi anomali kerapatan patahan dan rekahan sebagai batas daerah prospek panas bumi.

Citra landsat yang digunakan dalam penelitian ini bersumber dari data USGS (United State Geological Survey) tahun 2003 dengan menggunakan band 4-5-7 dan band 3-2-1 dalam proses pengolahannya.

\section{HASIL PENYELIDIKAN}

Berdasarkan hasil penarikan kelurusan patahan dan rekahan (Gambar 4) yang kemudian dimasukkan ke dalam diagram Roset (Gambar 5), arah kelurusan struktur utama di daerah Candi Umbul-Telomoyo terdiri dari 4 (empat) arah struktur utama, yaitu arah N 100-110\% $/ \mathrm{E}$ atau N 280-290 \% arah N 60-70\% atau N 240-250\%, arah N 20-30\% atau N 200-210\%, dan arah N $150-160 \%$ atau N $330-340 \%$.

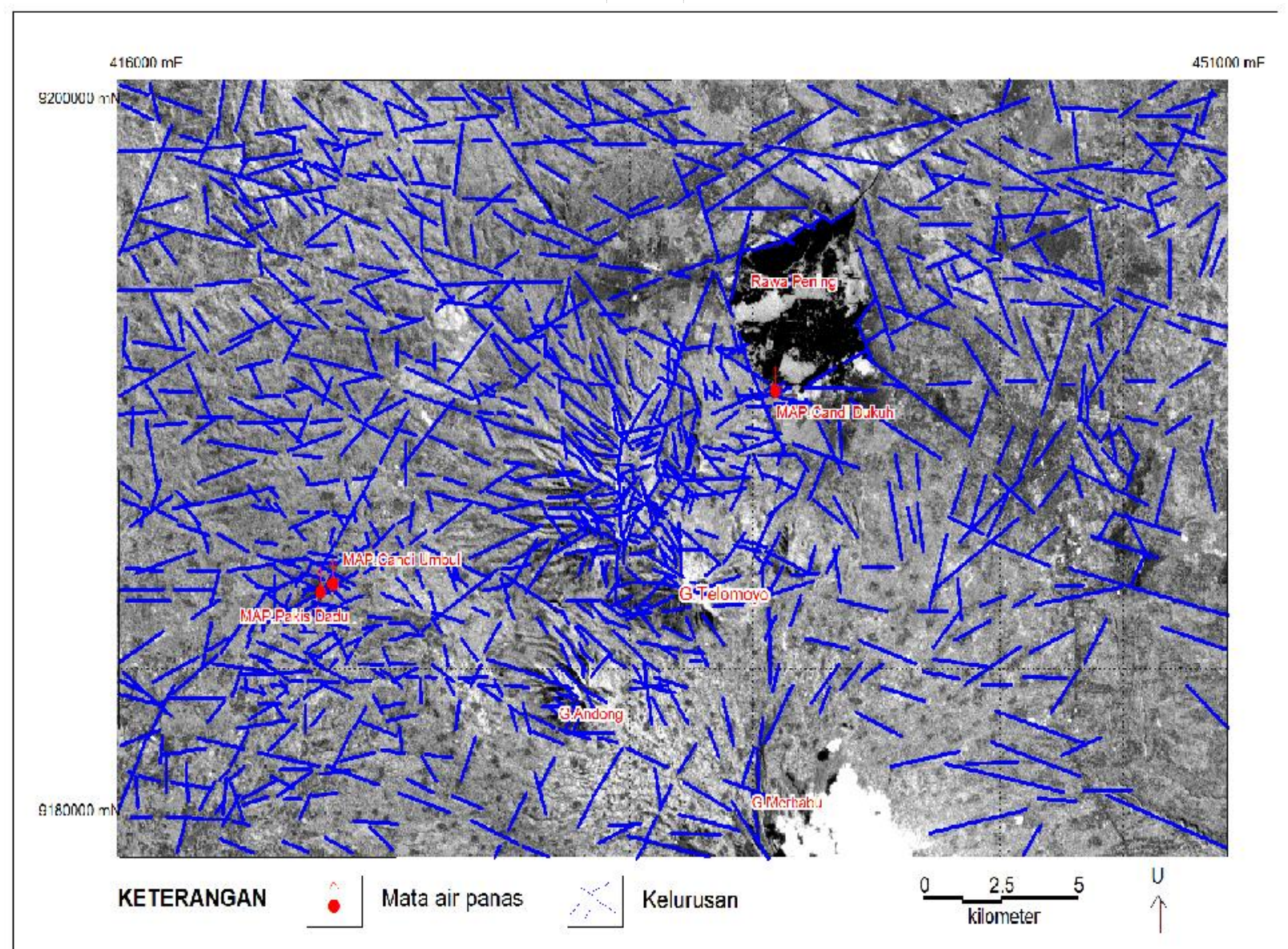

Gambar 4. Peta Kelurusan Daerah Panas Bumi Candi Umbul-Telomoyo 


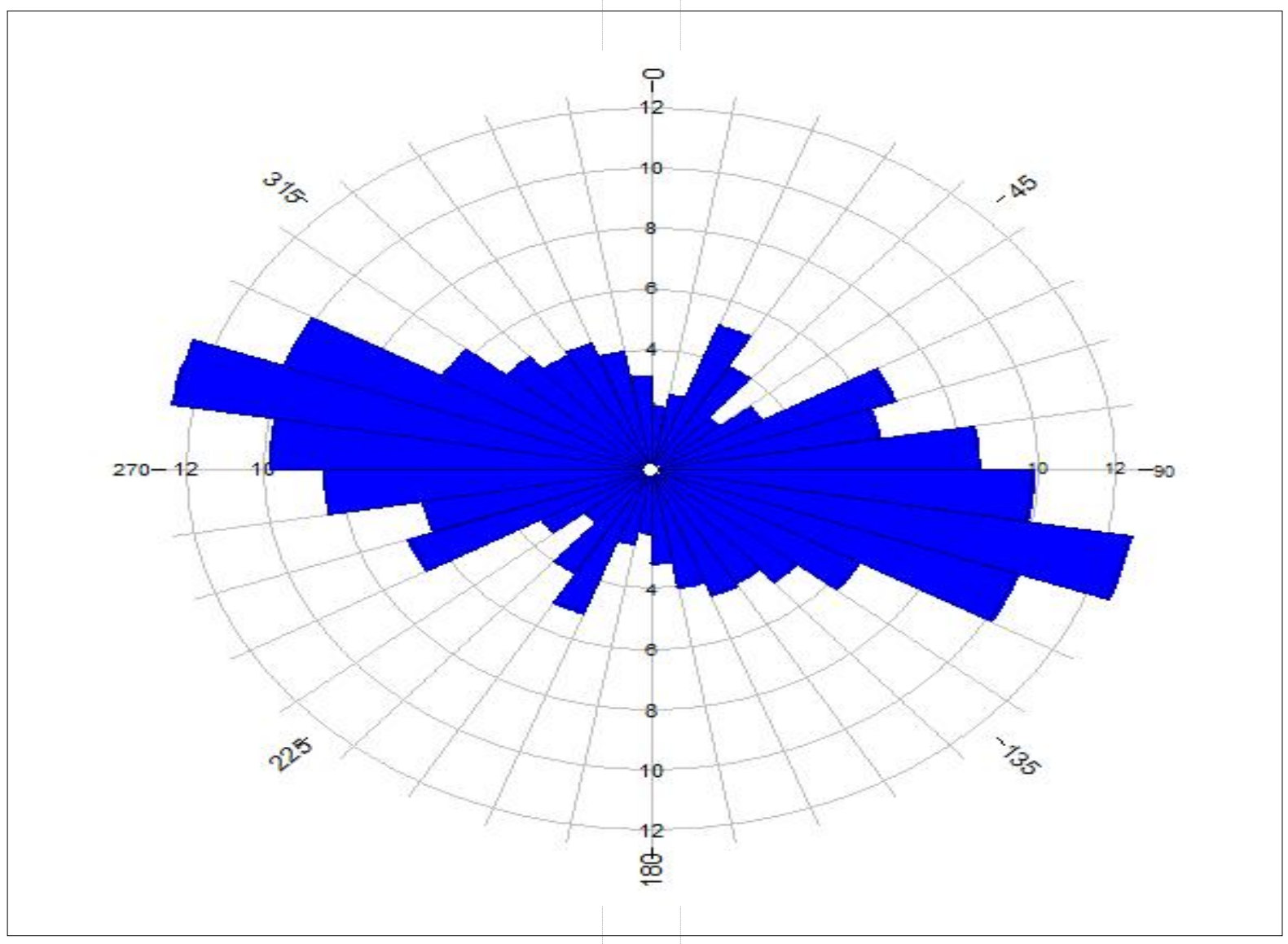

Gambar 5. Diagram Roset Pola Kelurusan

\section{Peta Kerapatan Patahan dan Rekahan}

Peta ini menggambarkan anomali kerapatan patahan dan rekahan yang diasumsikan sebagai recharge area yang memliki permeabilitas paling baik.

Anomali kerapatan patahan dan rekahan dengan nilai diatas $6 \mathrm{~km} / \mathrm{km}^{2}$ terdapat di bagian utara kerucut muda Gunung Telomoyo sampai daerah Candi Dukuh, di daerah sekitar manifestasi Candi Umbul, di lereng barat Gunung Andong, serta di bagian baratlaut Gunung Telomoyo (Desa Banyuurip) dan di perbukitan sebelah utara Kota Salatiga yaitu di daerah Bukit Payung (Gambar 6).

\section{Peta Kerapatan Perpotongan Patahan dan Rekahan}

Peta ini menggambarkan zona bukaan struktur (jog) dari hasil perpotongan kelurusan yang memiliki anomali kerapatan tinggi sebagai media potensial bagi fluida panas bumi muncul ke permukaan.

Zona bukaan struktur yang memiliki anomali kerapatan tinggi dengan nilai diatas $6 \mathrm{~km} / \mathrm{km}^{2}$ terdapat di bagian utara kerucut muda Gunung Telomoyo sampai daerah Candi Dukuh, di daerah sekitar manifestasi Candi Umbul, dan di baratlaut Gunung Telomoyo yaitu di sekitar Desa Ngadisari (Gambar 7).

\section{Peta Kompilasi Kerapatan Patahan dan Rekahan}

Peta ini merupakan peta kompilasi dari peta kerapatan patahan dan rekahan dan peta kerapatan perpotongan patahan dan rekahan. Dari peta ini dapat dideliniasi perkiraan daerah yang memiliki anomali kerapatan struktur geologi yang paling tinggi. Setelah dideliniasi, anomali kerapatan struktur geologi dengan nilai diatas $6 \mathrm{~km} / \mathrm{km}^{2}$ terletak di bagian utara kerucut muda Gunung Telomoyo yaitu dari lereng baratlaut kerucut muda Gunung Telomoyo memanjang ke utara-timurlaut sampai daerah Keningar dan Candi Dukuh dengan luas sekitar $39 \mathrm{~km}^{2}$ serta di daerah sekitar manifestasi Candi Umbul dengan luas sekitar $7 \mathrm{~km}^{2}$ (Gambar 8). 


\section{MAKALAH ILMIAH}

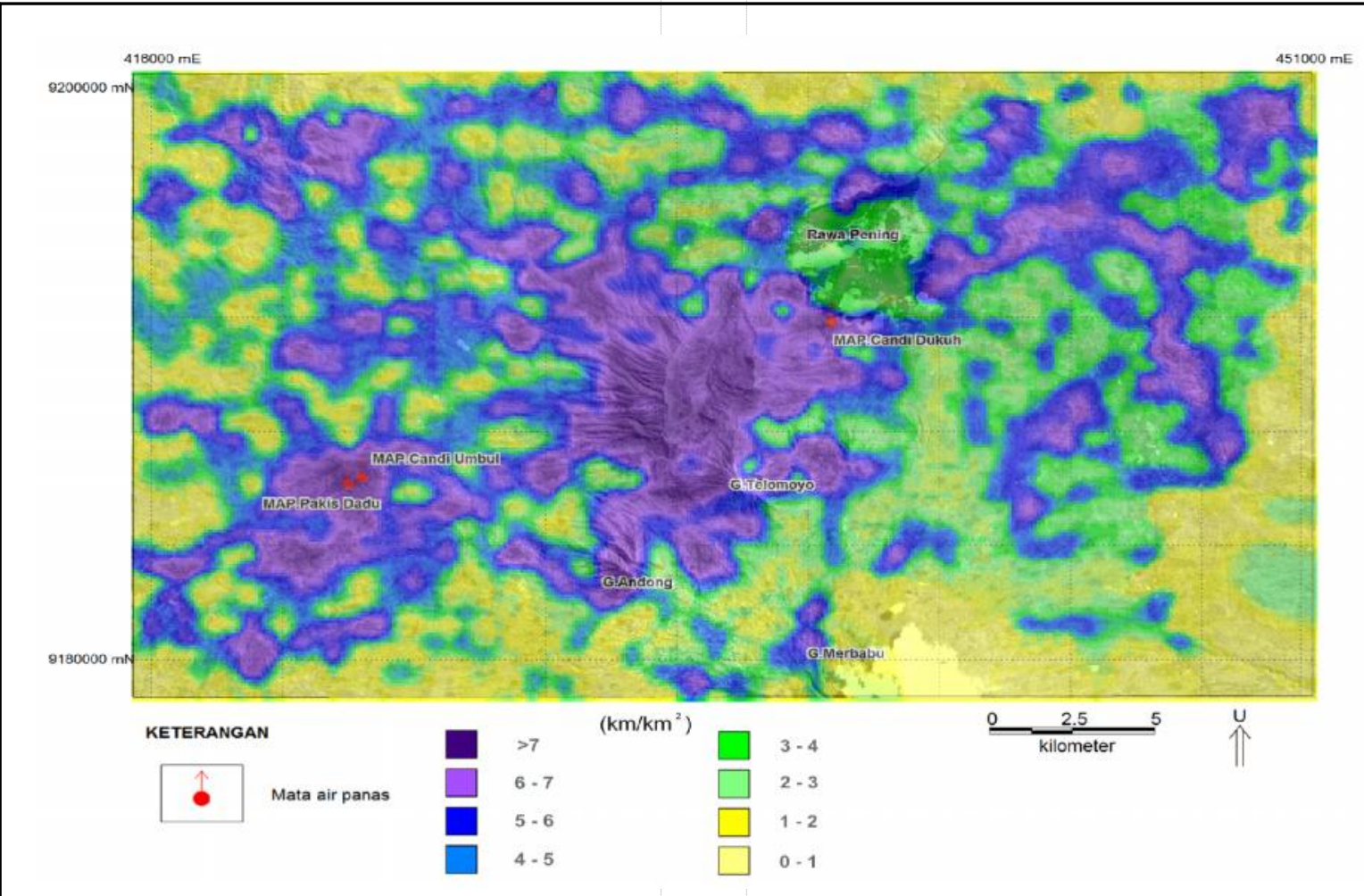

Gambar 6. Peta Kerapatan Patahan dan Rekahan Daerah Panas Bumi Candi Umbul-Telomoyo

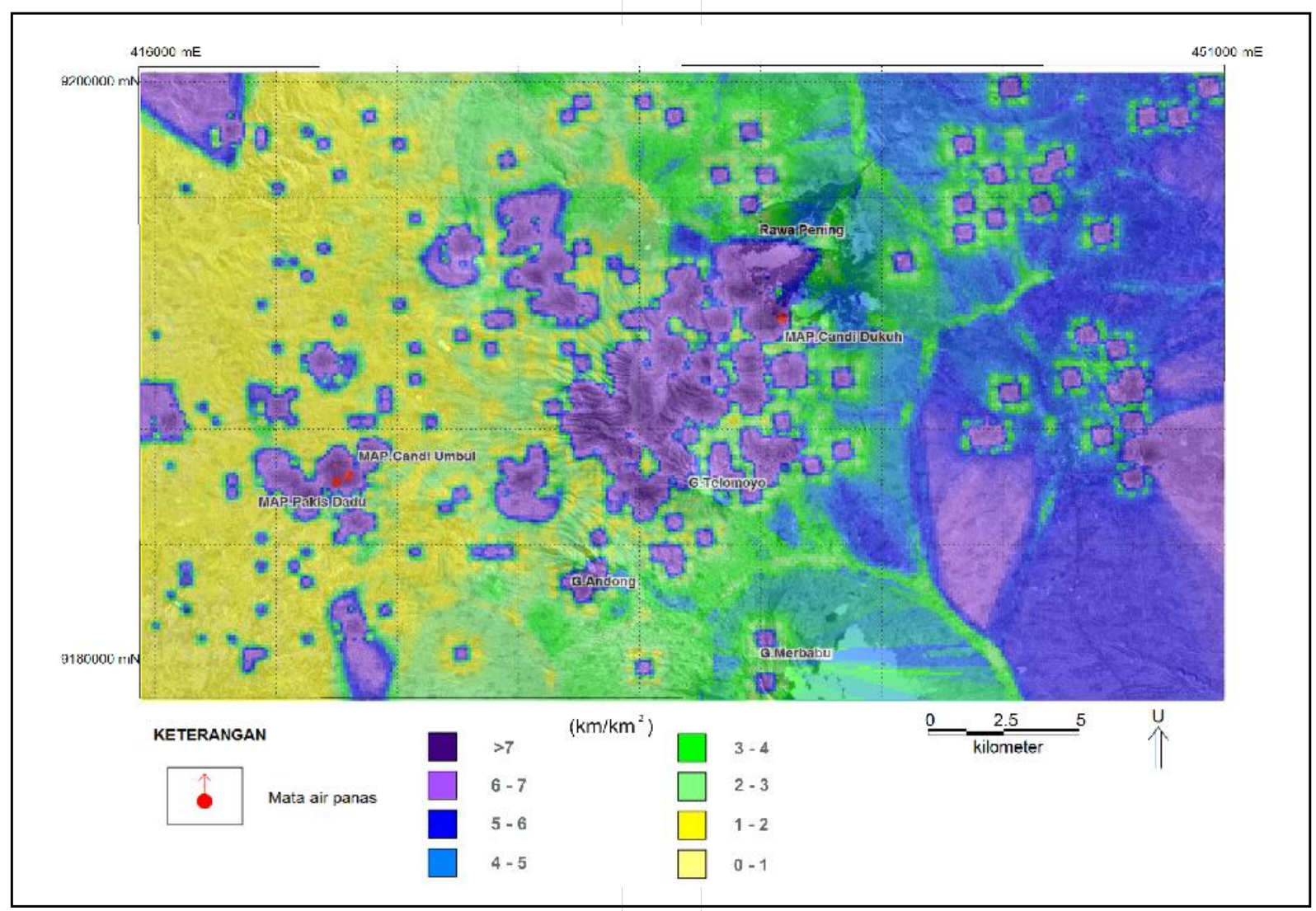

Gambar 7. Peta Kerapatan Perpotongan Patahan dan Rekahan Daerah Panas Bumi Candi Umbul-Telomoyo 


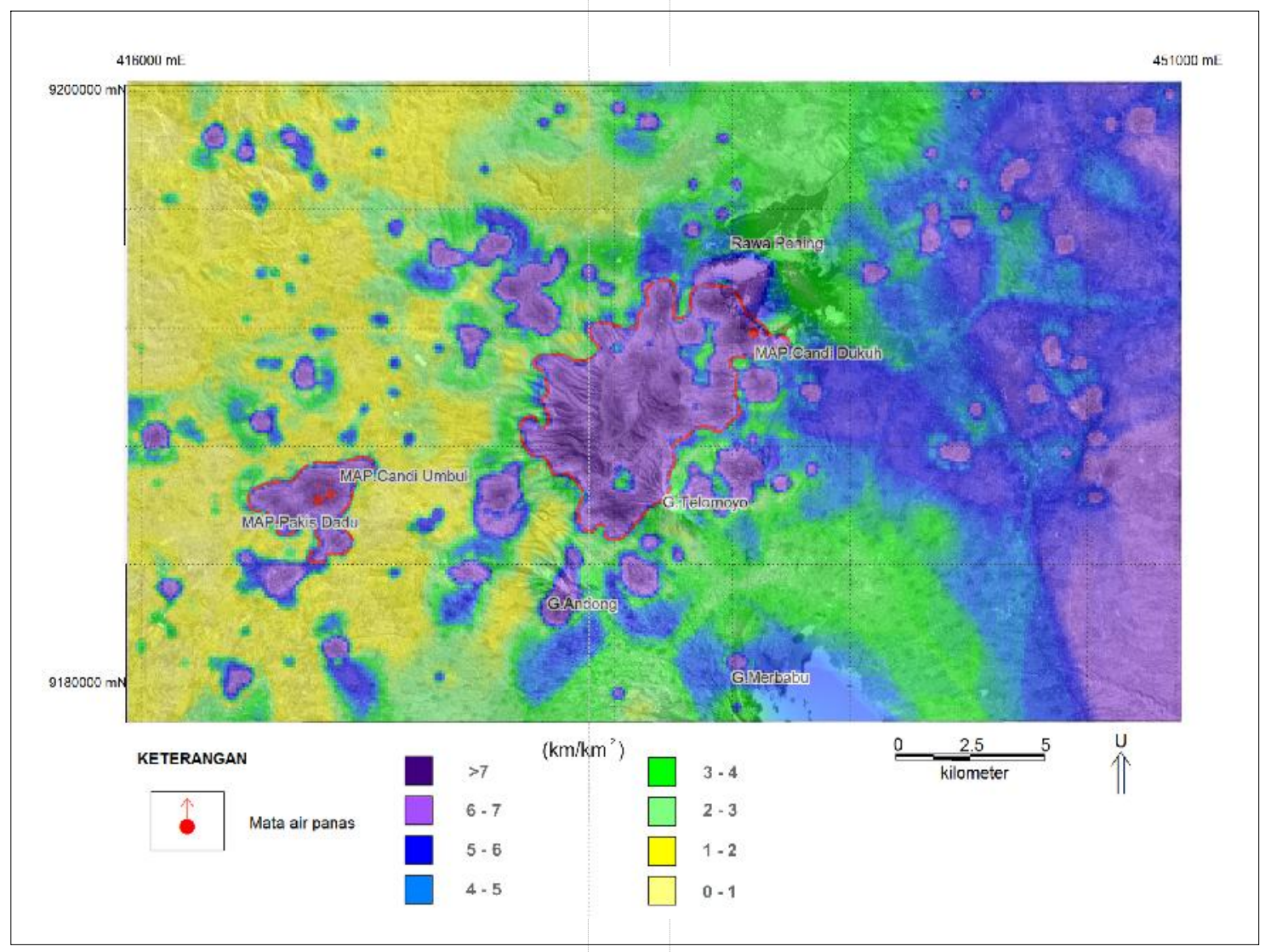

Gambar 8. Peta Kompilasi Kerapatan Patahan dan Rekahan Daerah Panas Bumi Candi Umbul-Telomoyo

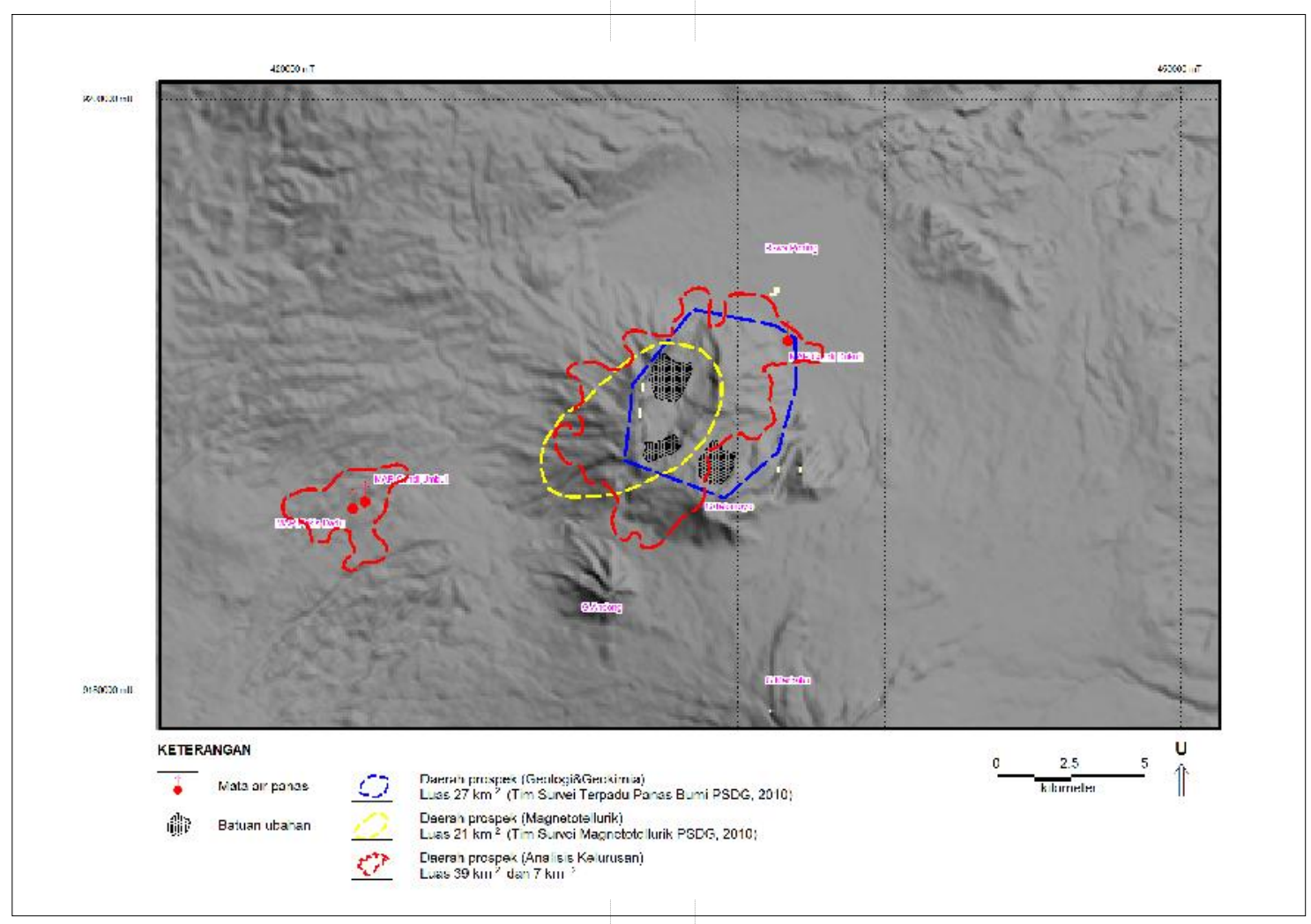

Gambar 9. Peta Kompilasi Geosains Daerah Panas Bumi Candi Umbul-Telomoyo 


\section{PEMBAHASAN}

Dari ke-empat arah kelurusan struktur utama tersebut, arah struktur yang paling dominan adalah arah $\mathrm{N} 100-110 \%$ atau $\mathrm{N}$ 280-290 \% E dan struktur yang berarah N 20$30 \%$ atau N 200-210\%. Struktur-struktur ini diperkirakan merupakan pola struktur termuda yang berkembang di daerah ini dan mengontrol pemunculan manifestasi panas bumi Candi Umbul-Telomoyo.

Arah utama struktur geologi di daerah ini sesuai dengan pola struktur regional (Gambar 2) yaitu searah dengan pola Jawa yang relatif berarah barat-timur.

Anomali kerapatan kelurusan yang tinggi menunjukkan bahwa daerah tersebut merupakan daerah prospek panas bumi yang memiliki kerapatan struktur geologi yang memadai untuk membentuk suatu sistem panas bumi.

Dari Peta Kompilasi Kerapatan Patahan dan Rekahan dapat diketahui bahwa daerah prospek panas bumi Candi Umbul-Telomoyo terletak di bagian utara kerucut muda Gunung Telomoyo yaitu dari lereng baratlaut kerucut muda Gunung Telomoyo memanjang ke utara-timurlaut sampai daerah Keningar dan Candi Dukuh dengan luas sekitar $39 \mathrm{~km}^{2}$ serta di daerah sekitar manifestasi Candi Umbul dengan luas sekitar $7 \mathrm{~km}^{2}$.

Apabila dibandingkan dengan peta kompilasi geosains (modifikasi dari Laporan Survei Terpadu Geologi dan Geokimia daerah Candi Umbul-Telomoyo dan Laporan Survei Magnetotellurik daerah Candi UmbulTelomoyo, PSDG 2010), daerah prospek panas bumi Candi Umbul-Telomoyo yang dideliniasi dari peta kerapatan struktur ini mendukung hasil survei tersebut

(Gambar 9).
Oleh karena itu metode penarikan kelurusan pada citra landsat ini layak digunakan sebagai metode awal yang dilakukan untuk suatu kegiatan eksplorasi panas bumi.

\section{KESIMPULAN}

Hasil penelitian dengan metode pemetaan kerapatan struktur menunjukkan bahwa daerah prospek panas bumi Candi Umbul-Telomoyo terletak di bagian utara kerucut muda Gunung Telomoyo yaitu dari lereng baratlaut kerucut muda Gunung Telomoyo memanjang ke utara-timurlaut sampai daerah Keningar dan Candi Dukuh dengan luas sekitar $39 \mathrm{~km}^{2}$, serta di daerah sekitar manifestasi Candi Umbul dengan luas sekitar $7 \mathrm{~km}^{2}$.

Daerah prospek panas bumi yang dideliniasi dengan metode ini ternyata sangat sesuai dengan hasil survei sebelumnya (survei terpadu geologi, geokimia, dan geofisika, serta survei magnetotellurik).

Metode analisis struktur geologi berdasarkan penarikan kelurusan citra landsat sangat perlu untuk dilakukan pada tahap awal eksplorasi panas bumi. Dari hasil analisis ini bisa diketahui daerah yang memiliki anomali tinggi kerapatan struktur geologi yang berpotensi sebagai daerah prospek bagi pengembangan panas bumi.

\section{UCAPAN TERIMA KASIH}

Ucapan terima kasih kami ucapkan kepada rekan-rekan dan tim editor yang telah mengoreksi dan memberikan saran dalam penyusunan makalah ini. Serta kepada dewan redaksi yang telah memberikan kesempatan makalah ini sehingga dapat diterbitkan.

\section{DAFTAR PUSTAKA}

Browne, P.R.L., 1989, Investigation at The Rotokawa Geothermal Field Taupo Volcanic Zone, Journal of Geothermal Research Society, New Zealand.

http://glovis.usgs.gov, diakses tanggal 22 Mei 2010

Robert E.Thaden, dkk, (1975), Geologi Lembar Magelang dan Semarang, Pusat Penelitian dan Pengembangan Geologi.

Soengkono, S., Te Kopia geothermal system (New Zealand) - the relationship between its structure and extent, Geothermics 28 (1999a), page 767-784. 
Soengkono, S., Analysis of Digital Topographic Data for Exploration and Assessment of Geothermal System, Proceeding 21st New Zealand Geothermal Workshop (1999b).

Suryantini and Hendro Wibowo, Application of Fault and Fracture Density (FFD) Method for Geothermal Exploration in Non-Volcanic Geothermal System; a Case Study in Sulawesi-Indonesia.Proceedings World Geothermal Congress 2010. Bali, Indonesia.

Sugeng, 2005. Kajian Analisis Kelurusan Struktur dengan Citra Landsat Digital untuk Eksplorasi Mineralisasi Emas di Daerah Bayah, Kabupaten Lebak, Jawa Barat, Pertemuan IImiah Tahunan MAPIN XIV.

Sabins, FF, 1996. Principles And Interpretation. New York: WH Freeman And Company.

Sribudiyani, Nanang Muchsin, Rudy Ryacudu, Triwidiyo Kunto, Puji Astono, Indra Prasetya, Benyamin Sapiie, Sukendar Asikin, Agus H. Harsolumakso, Ivan Yulianto, 2003, The Collision of The East Java Microplate and Its Implication for Hydrocarbon Occurrences in The East Java Basin. Proceeding Indonesian Petroleum Association, Twenty-Nine Annual Convention and Exibition.

Tim Survei Terpadu Geologi dan Geokimia, 2010. Laporan Survei Terpadu Geologi dan Geokimia Daerah Panas Bumi Candi Umbul-Telomoyo, Provinsi Jawa Tengah, Pusat Sumber Daya Geologi, Bandung (unpublished report).

Tim Survei Magnetotellurik, 2010. Laporan Survei Magnetotellurik Daerah Panas Bumi Candi Umbul-Telomoyo, Provinsi Jawa Tengah, Pusat Sumber Daya Geologi, Bandung (unpublished report). 